\title{
PodmiotoWość PRAWNA NA TLE PODZIAŁU PRAWA NA PRYWATNE I PUBLICZNE
}

Pojęcie podmiotu prawnego przedstawiać można w kontekście takich konstrukcji, jak zakres normy prawnej, prawo podmiotowe czy stosunek prawny. Normy prawne są adresowane do określonych podmiotów, wyznaczają im prawa i obowiązki jako stronom stosunków prawnych. Bez podmiotów wymienione kategorie nie mogłyby społecznie zaistnieć i funkcjonować. Podmiot prawny to nie jedynie obiekt zarachowania czy punkt zaczepienia dla praw i obowiązków, to coś więcej, to byt prawny, swego rodzaju jestestwo, którego istnienie warunkuje obowiązywanie normy prawnej czy powstanie prawa podmiotowego. W poniższych rozważaniach chciałbym podjać się próby odpowiedzi na pytania: czy na rozumienie i kategoryzację podmiotowości prawnej jakiś wpływ ma fundamentalne rozróżnienie, czy też podział prawa - na prywatne i publiczne; czy ustalenia w dziedzinie podmiotowości, które są udziałem doktryny prawa cywilnego, są uniwersalne i mogą być przenoszone na obszar innych gałęzi prawa; wreszcie czy można utożsamiać ze sobą pojęcia podmiotowości i osobowości prawnej.

\section{Znaczenie pojęcia podmiot prawny}

Problematyka podmiotowości prawnej należy do podstawowych zagadnień prawoznawstwa i stanowi przedmiot badań teorii prawa oraz

* Dr hab., Uniwersytet w Białymstoku; e-mail: adoliwa@uwb.edu.pl, https://orcid.org/ 0000-0002-0752-7708. 
dogmatyk poszczególnych gałęzi prawa; w szczególności znaczny dorobek $\mathrm{w}$ tej mierze jest udziałem doktryny prawa cywilnego i administracyjnego. Współcześnie przedmiotem refleksji naukowej są albo wkrótce staną się zagadnienia: podmiotowości prawnej jednostki ludzkiej w kontekście rozwoju biotechnologii medycznej, zakres podmiotowości cywilnoprawnej jednostek organizacyjnych, w tym zwłaszcza niebędących osobami prawnymi, podmiotowość publicznoprawna oraz możliwa prawna personifikacja zwierząt i sztucznej inteligencji ${ }^{1}$. Wspomnieć można także o badaniach nad odpowiedzialnością karną osób prawnych² .

Biorąc za punkt wyjścia efekt dociekań filozoficznych i etymologicznych, w nauce prawa wyrażeniu „podmiot” przypisywano dawniej (przez odwołanie się do łacińskiego słowa subiectum, pochodzącego od subicere, znaczącego tyle, co poddany, podwładny, podległy, podporządkowany ${ }^{3}$ ) sens następujący: podmiot to ktoś, kto jest prawu poddany. Pojęcie podmiotu wyjaśniano następnie, zwłaszcza pod wpływem koncepcji prawa natury, biorąc za podstawę znaczeniową łacińskie słowo substratus - podściółka, pochodzące od substernere ${ }^{4}$, które w języku filozofii oznaczało substrat (substancję) będący bytem, istnieniem, istotą rzeczy ${ }^{5}$. Prowadziło to do konstatacji, że podmiot to ktoś, kto realnie istnieje, mając przy tym pewne cechy (atrybuty). Początkowo pod pojęciem podmiotu prawa rozumiano jednostkę prawu podległą i podporządkowaną, następnie zaś jednostkę wyposażoną $\mathrm{w}$ atrybut autonomii woli i wyposażoną $\mathrm{w}$ prawa podmiotowe oraz ponoszącą majątkową odpowiedzialność za swoje zobowiązania ${ }^{6}$.

1 Zob. A. Breczko, Podmiotowość prawna człowieka w warunkach postępu biotechnomedycznego, Białystok 2011, passim; M. Wach, Status ułomnych osób prawnych w polskim prawie cywilnym, Warszawa 2008, passim; J. Filipek, Podmiotowość w prawie administracyjnym, w: Podmioty administracji publicznej i prawne formy ich dziatania. Studia i materiaty $z$ konferencji naukowej poświęconej jubileuszowi 80-tych urodzin profesora Eugeniusza Ochendowskiego, Torun 2005; M. Kruszewska-Gagoś, Podmiotowość publicznoprawna gminy, Lublin 2009, passim; M. Kalinowski, Podmiotowość prawna podatnika, Torun 1999, passim.

2 Zob. B. Namysłowska-Gabrysiak, Odpowiedzialność karna osób prawnych, Warszawa 2003, passim.

3 Zob. W. Boryś, Stownik etymologiczny języka polskiego, Kraków 2005, hasło: Podmiot, s. 452; zob. też Stownik łacińsko-polski, red. M. Plezia, t. 5, Warszawa 1999, s. 244-245.

4 Zob. Stownik łacińsko-polski, t. 5, s. 264.

5 Zob. A.R. Lacey, Stownik filozoficzny, tłum. R. Matuszewski, Poznań 1999, s. 283 i n.

6 Por. M. Kalinowski, Podmiotowość prawna podatnika, s. 18. 
Dziś przyjmuje się na ogól, przy założeniu performatywnej funkcji języka prawnego ${ }^{7}$, że podmiot prawny, jako adresat normy prawnej to nie tyle ktoś realnie istniejący, posiadający zespół istotnych prawnie cech, co raczej ktoś, kogo obowiązująca norma prawna "postawiła” w określonej sytuacji, w relacji do innego podmiotu, jako uprawnionego lub obowiązanego. Podstawą takiej koncepcji podmiotu jest stwierdzenie, że ustanowione przez normę prawną prawa i obowiązki nie służą opisowi rzeczywistości, lecz jej normatywnej kwalifikacji i przedstawieniu w sposób relacyjny. Ustanowienie norm prawnych $\mathrm{w}$ tym sensie prowadzi do zmian społecznych, polegających zwłaszcza na tym, że określone podmioty uzyskują kwalifikacje będące skutkiem wypowiedzi prawodawcy, a w określonych sytuacjach powinny zachować się zgodnie z normami prawnymi.

Tym samym pojęcie podmiotu prawnego służy wyjaśnieniu znaczenia normy prawnej i skutków jej oddziaływania na rzeczywistość społeczną ${ }^{8}$. Przepisy prawne wywołują przede wszystkim skutek konwencjonalny w postaci wyznaczenia podmiotom określonych praw i obowiązków. W konsekwencji wyrażenia "podmiot prawny” i „podmiotowość prawna" nie odnoszą się do świata rzeczywistości przyrodniczej, lecz do kwalifikacji, które prawo nadaje jego elementom ${ }^{9}$. Pojęcie podmiotu prawa należy postrzegać jako konstrukcję prawną złożoną ze znaczenia norm prawnych i innych wyznaczników ludzkiego zachowania dopuszczonych przez tę normę (takich jak oświadczenia woli, orzeczenia sądowe, akty administracyjne, zasady normatywne inne niż prawo pozytywne, jak np. zasady współżycia społecznego) ${ }^{10}$.

Wspomniane kwalifikacje prawo nadaje jednostkom ludzkim, jak również ich zorganizowanym grupom, a nawet masom majątkowym. Według takiego ujęcia podmiotowość prawna ma charakter jednolity i pozwalający się nią posługiwać bez względu na przynależność danej regulacji prawnej do poszczególnych gałęzi. Podmiot prawny pozostaje w każdym przypadku konstrukcją prawną, stanowiącą jakiś zespół norm,

7 Por. J.L. Austin, Mówienie i poznawanie, Warszawa 1993; J. Pieńkos, Podstawy juryslingwistyki. Jezyk w prawie - Prawo w jezzyku, Warszawa 1999.

8 J. Frąckowiak, Jednostka organizacyjna jako substrat osoby prawnej i ustawowej, w: Rozprawy prawnicze. Księga pamiątkowa Profesora Maksymiliana Pazdana, red. L. Ogiegło, W. Popiołek, M. Szpunar, Kraków 2005, s. 900.

9 Tak M. Kalinowski, Podmiotowość prawna podatnika, s. 20-21.

10 Zob. J. Frąckowiak, w: System Prawa Prywatnego, t. 1. Prawo cywilne - część ogólna, red. M. Safjan, Warszawa 2007, s. 1017 i 1027. 
mimo tego nawet, że nadawane mu przez prawo kwalifikacje mogą się różnić ze względu na metodę i przedmiot regulacji danej gałęzi prawa (i przybierać postać praw podmiotowych, roszczeń, zarzutów, obowiązków, kompetencji itd. $)^{11}$.

Podmiotowość prawna jest istotnym elementem konstrukcyjnym prawa, gdyż współokreśla strukturę normy prawnej jako reguły postępowania. W stanie faktycznym podlegającym prawnej regulacji istotne znaczenie ma kwestia, kto powinien zachować się w określony sposób. Chodzi w takim wypadku o określenie zakresu podmiotowego danej regulacji prawnej. Obowiązująca norma prawna jest do kogoś adresowana, a konkretyzacja adresata abstrakcyjnej normy prawnej następuje $\mathrm{w}$ ramach określonego stosunku prawnego. Ten ostatni powstaje np. na podstawie określonego zdarzenia prawnego, chociażby czynności prawnej (zwłaszcza umowy), a w jego ramach określony podmiot jest zobowiązany lub uprawniony ${ }^{12}$. Oczywiście prócz określonego podmiotu elementami niezbędnymi do ustalenia konkretnego stosunku prawnego są fakty prawne powodujące, że w określonym układzie powstaje dany stosunek, a także zachowania uznawane za przedmiot (lub treść) danego stosunku ${ }^{13}$. W teorii prawa stwierdza się też na ogół, że wyrażenie "stosunek prawny” służy do opisu konsekwencji obowiązywania określonych norm prawnych. Wspomniane konsekwencje (skutki prawne) zwykle mają konkretnych adresatów; dotyczą kogoś; określone podmioty mają jakieś prawa (uprawnienia) i obowiązki właśnie z powodu obowiązywania określonych norm prawnych. Przy tym zauważyć należy, że podmiotowość prawną ustawodawca sankcjonuje albo przyznaje określonym jednostkom, jednostkom organizacyjnym albo i masom majątkowym nie arbitralnie i bez żadnej społecznej, gospodarczej czy innej potrzeby, ale zwłaszcza z uwagi na określoną aksjologię oraz ze względu na określoną rzeczywistość społeczno-gospodarczą ${ }^{14}$.

Rozwój pojęcia podmiotu prawnego pozostaje w związku z rozwojem idei praw podmiotowych, rozumianych początkowo $\mathrm{w}$ myśl

11 Zob. M. Kalinowski, Podmiotowość prawna podatnika, s. 22. Zob. też J. Wróblewski, Teorie osób prawnych - zarys podejścia semiotycznego, w: Studia z prawa cywilnego. Księga pamiatkowa dla uczczenia 50-lecia pracy naukowej prof. dr. hab. Adama Szpunara, red. A. Rembieliński, Łódź 1983, s. 78 i n.

12 Zob. Z. Ziembiński, Problemy podstawowe prawoznawstwa, Warszawa 1980, s. 334 i n.

13 Zob. tamże, s. 336 i n.

14 Zob. M. Kalinowski, Podmiotowość prawna podatnika, s. 23. 
prawnonaturalnego ujęcia jako prawa przyrodzone, przynależne każdemu człowiekowi jako odrębnemu i autonomicznemu podmiotowi porządku prawnego ${ }^{15}$. Tak więc zasadniczo podmiotowość prawna jest definiowana przez odwołanie się do kategorii praw (uprawnień) i obowiązków danego podmiotu bądź do kategorii określonej sytuacji jednego podmiotu wobec innego, określonej czy kwalifikowanej przez normę prawną. Według pierwszego podejścia za podmiot prawny uważa się jednostkę mającą z mocy ustawy zdolność prawną, tj. zdolność do posiadania różnego rodzaju praw i obowiązków, zaś samo prawo jest podstawą opisu właściwości jednostki jako podmiotu prawnego. Natomiast w drugim wypadku prawo służy kwalifikacji określonej rzeczywistości; służy do normatywnej kwalifikacji nie tyle właściwości podmiotu, co raczej do opisu relacji - prawem unormowanej - $w$ jakiej pozostaje on wobec innego podmiotu ${ }^{16}$.

Tak więc pojęcie podmiotu prawnego wyjaśnić da się przez stwierdzenie, że chodzi o podmiot jakiegoś konkretnego prawa podmiotowego lub stosunku prawnego. $Z$ tym że podejście takie jest właściwe dla gałęzi prawa normujących prawa i obowiązki określonego typu (np. o charakterze majątkowym lub osobistym) skonkretyzowanych podmiotów, które na podstawie przyjętego katalogu zdarzeń prawnych znalazły się w sytuacji współzależności swojej sytuacji prawnej; koncepcja taka jest przyjmowana na gruncie przepisów prawa cywilnego, administracyjnego, prawa pracy. Natomiast bez powiązania z kategorią konkretnego stosunku prawnego pojęcie podmiotu prawnego wyjaśniane jest na gruncie norm prawnych, które ustanawiają generalne prawa i obowiązki (a zwłaszcza obowiązki) wszystkich wobec wszystkich, jak np. na gruncie przepisów prawa karnego, konstytucyjnego. W tym sensie teoretycznym podmiot prawny to szerzej podmiot - adresat normy prawnej, któremu przypisane są różne obowiązki i różne prawa (uprawnienia) ${ }^{17}$.

Problematyka podmiotowości prawnej w opisanym powyżej kontekście ukazuje swoją doniosłość praktyczną i teoretyczną. Bez większej przesady można stwierdzić, że generalnie przedmiotem rozważań doktryny prawa, w tym zwłaszcza prawa cywilnego, jest współzależność sytuacji

\footnotetext{
15 Zob. tamże, s. 17-19.

16 Por. tamże, s. 20-21.

17 Por. Z. Ziembiński, Problemy podstawowe prawoznawstwa, s. 334.
} 
prawnej poszczególnych podmiotów ze względu na ustanowione i obowiązujące generalne normy cywilnoprawne ${ }^{18}$.

\section{Prawo publiczne a prawo prywatne}

System prawny to uporządkowany zbiór norm, cechujący się formalną zupełnością i spójnością. W układzie pionowym prawo jest uporządkowane hierarchicznie, zaś w układzie poziomym dzieli się na gałęzie, wyróżniane według różnych kryteriów (np. metody, przedmiotu, podmiotu regulacji $)^{19}$. System prawny jest też opisywany za pomocą wyróżnienia pojęć prawa publicznego i prywatnego, które są nazywane „ponadgałęziowymi działami prawa"20. Za zasadniczy element składowy prawa publicznego, decydujący o jego istocie, uważa się prawo administracyjne, zaś w odniesieniu do prawa prywatnego rolę taką przypisuje się prawu cywilnemu. Wyróżnienie w systemie prawnym części składowych w postaci prawa prywatnego i publicznego ma charakter zasadniczy do tego stopnia, że wpływa na istotę prawa cywilnego - jako prywatnego i prawa administracyjnego - jako publicznego ${ }^{21}$.

Rozróżnienie prawa na prywatne i publiczne ma swoją imponującą, sięgającą starożytności historięę2, a współcześnie oparte jest na aprobacie pewnych wartości i określonej ideologii społeczno-politycznej ${ }^{23}$. Zwolennicy omawianego opisu systemu prawnego $\mathrm{w}$ promowaniu pojęć prawa prywatnego i publicznego widzą metodę afirmacji - odpowiednio

18 Zob. tenże, O metodzie analizowania stosunku prawnego, Państwo i Prawo 1967, z. 2, s. 198 i n.

19 Zob. S. Wronkowska, Podstawowe pojęcia prawa i prawoznawstwa, Poznań 2005, s. 104 i n.

20 Zob. H. Rot, Problem dychotomii prawa publicznego i prywatnego, Przegląd Prawa i Administracji 1976, t. 7, s. 23.

21 Zob. Z. Radwański, Pojęcie prawa cywilnego w świetle kodeksu cywilnego (uwagi de lege lata $i$ de lege ferenda), w: Polskie prawo prywatne w dobie przemian. Ksiegga jubileuszowa dedykowana Profesorowi Jerzemu Mtynarczykowi, Gdańsk 2005, s. 31.

22 Zob. Z. Duniewska, w: System Prawa Administracyjnego, t. 1. Instytucje prawa administracyjnego, red. Z. Niewiadomski, Warszawa 2010, s. 152.

23 Tak J. Nowacki, Prawo publiczne, prawo prywatne, Katowice 1992, s. 132; por. T. Bigo, Związi publiczno-prawne w świetle ustawodawstwa polskiego, Warszawa 1928, s. 1 i n. 
autonomii jednostki bądź sprawnej i silnej władzy państwowej (publicznej ${ }^{24}$. Sformułowane w nauce prawa najważniejsze teorie rozróżnienia prawa na publiczne i prywatne to: teorie interesu, teorie podmiotu i przedmiotu normowania, teorie metody regulacji prawnej, teorie zadań, teorie rzecznika dobra, teorie woli lub inicjatywy stron, teorie władzy publicznej lub podporządkowania, teorie techniki prawodawczej, funkcji prawa i odmienności przepisów prawnych, teorie tradycji, teorie właściwości sądowej, teorie sankcji oraz liczne teorie mieszane ${ }^{25}$.

Zwykle przedstawiciele nauki znaczenie omawianego rozróżnienia na prawo publiczne i prywatne doceniają, gdyż za jego pomocą dokonać można systematyki: prawa, norm prawnych i metod regulacji prawnej; rozgraniczenia sankcji prawnych i dróg ochrony prawnej, ale można także przeprowadzić systematykę podmiotów stosunków prawnych i ich kompetencji prawnych ${ }^{26}$. Celowość wyróżniania pojęć prawa publicznego i prywatnego bywa czasem kwestionowana, uznać jednak należy ten zabieg za wartościowy teoretycznie oraz praktycznie, przede wszystkim dlatego, że ukazuje różnice co do istoty, w tym funkcji, jak również co do metody regulacji wyróżnionych dziedzin i gałęzi prawa ${ }^{27}$, a przez to także podkreśla różnice co do istoty i metody oraz celów działania ich podmiotów ${ }^{28}$.

Cechą prawa publicznego jest regulacja działalności państwa i innych podmiotów publicznych oraz ludzi jako obywateli w stosunkach z państwem. W prawie publicznym występuje podporządkowanie jednostki podmiotowi władzy, a ten ostatni działa $w$ interesie publicznym, interesie ogółu, dążąc do realizacji i ochrony wartości wspólnych dla ogółu. $\mathrm{Z}$ kolei $\mathrm{w}$ prawie prywatnym podmioty stosunków prawnych są równorzędne i względem siebie autonomiczne, a regulacja prywatnoprawna ma przede wszystkim na celu ochronę interesów - w tym majątkowych i osobistych - prywatnych, jednostkowych ${ }^{29}$. Prawo publiczne $\mathrm{w}$ imię interesu publicznego porządkuje stosunki, w które wchodzą jednostki

24 Zob. Z. Duniewska, w: System Prawa Administracyjnego, t. 1, s. 153.

25 Zob. S. Fundowicz, Dychotomiczny podziat prawa, Samorząd Terytorialny 2000, nr 1-2, s. 52 i n.; zob. też Z. Duniewska, w: System Prawa Administracyjnego, t. 1, s. 154 i n.; System Prawa Prywatnego, t. 1, s. 31 i n.

26 Zob. S. Włodyka, Problem struktury prawa, Państwo i Prawo 1995, z. 4, s. 7 i n.

27 Zob. M. Zimmermann, Z zagadnień definicji prawa administracyjnego, Acta Universitatis Wratislaviensis. Prawo 1964, t. 12, nr 19, s. 16.

28 Por. J. Nowacki, Prawo publiczne, prawo prywatne, s. 50-69.

29 Por. Z. Duniewska, w: System Prawa Administracyjnego, t. 1, s. 156 i n. 
jako obywatele oraz wzajemne stosunki państw między sobą. Natomiast prawo prywatne $\mathrm{w}$ imię interesu prywatnego porządkuje wzajemne stosunki między jednostkami ${ }^{30}$.

Cechą prawa prywatnego jest to, że treść stosunków prawnych jest co do zasady kształtowana przez same strony, w szczególności za pomocą umowy. Z kolei $\mathrm{w}$ prawie publicznym występuje podmiot silniejszy (potentior persona), który narzuca treść stosunku prawnego i dysponuje możliwością użycia przymusu państwowego ${ }^{31}$. Stosunek prawny kształtowany w oparciu o normy prawa publicznego zakłada zwierzchnią zależność między stronami, zaś w przypadku stosunku cywilnoprawnego (prywatnoprawnego) brak takiej zależności ${ }^{32}$. W przeciwieństwie do prawa prywatnego, którego celem jest ochrona osobistych i majątkowych interesów jednostek, prawo publiczne dotyczy zadań publicznych, realizowanych przez podmioty publiczne ${ }^{33}$. Istotne i interesujące jest także to, że normy prawa administracyjnego, jako publicznego, stanowią o prawach i obowiązkach władz administracyjnych wobec jednostek (i vice versa), zaś normy prawa cywilnego (prywatnego) przeciwnie, regulują prawa i obowiązki jednostek w stosunku do innych jednostek. Trafne jest przy tym spostrzeżenie, że korzystając z przepisów prawa prywatnego, władza administracyjna zrównuje się z jednostką i „,schodzi do roli podmiotu prywatnego" 34 .

We współczesnym piśmiennictwie za główne kryterium wyróżnienia pojęć prawa publicznego i prywatnego, a zarazem za istotną cechę stosunków prawnych i podmiotów podlegających regulacji tak kwalifikowanych norm uznaje się metodę działania prawa, tj. kształtowania stosunków prawnych i sytuacji prawnych. Jedna metoda, prywatnoprawna, polega na przeważającej równorzędności i autonomiczności podmiotów, druga zaś - publicznoprawna, na dominacji, władczości, nadrzędności i podporządkowaniu. Obie metody są zdeterminowane określonymi

30 Zob. J. Nowacki, Prawo publiczne, prawo prywatne, s. 9.

31 Zob. J. Radwanowicz, Istota i znaczenie pojęcia przymusu administracyjnego, w: Koncepcja systemu prawa administracyjnego, red. J. Zimmermann, Warszawa 2007, s. 131 i n.

32 Zob. L. Rajca, Gmina jako podmiot władzy publicznej i jako właściciel mienia, Warszawa 2001, s. 76-77.

33 Zob. W. Łączkowski, Ustrojowe podstawy prawa publicznego, w: Studia z Prawa Publicznego, t. 1, Lublin 1999, s. 15.

34 Tak A. Peretiatkowicz, Podstawowe pojęcia prawa administracyjnego, Poznań 1947, s. 10. 
założeniami aksjologicznymi, w szczególności wyrażanymi w zasadach danej gałęzi prawa. Nie zachodzi w tej mierze zupełna rozłączność; tak w domenie stosunków regulowanych przez prawo cywilne, jak i administracyjne wskazane wyżej metody nie działają na zasadzie wyłączności $^{35}$. Co więcej, występuje nawet swoista konwergencja metod regulacji prawnej $^{36}$ i również podmioty prawa publicznego mogą być stroną stosunków prawnych kształtowanych na zasadzie względnej równorzędności i autonomii. Z innej perspektywy odnotowuje się w nauce zjawisko publicyzacji prawa prywatnego (za przykład można podać ostatnie zmiany w konstrukcji przedawnienia roszczeń majątkowych, gdzie tradycyjną dla prawa prywatnego regułę vigilantibus iura scripta sunt zastąpiono rozwiązaniem polegającym na uwzględnianiu z urzędu przez sąd upływu terminu przedawnienia roszczenia przedsiębiorcy przysługującego przeciwko konsumentowi), które definiowane jest jako proces odchodzenia od założeń klasycznego prawa cywilnego (np. pacta sunt servanda) ${ }^{37}$.

Oczywiście zarówno w obrębie prawa prywatnego, jak i publicznego pojęcie podmiotowości odgrywa istotną rolę, będąc zresztą jednym z kryteriów wyróżniania tych części systemu obowiązującego prawa. Należy się przy tym zastanowić, czy zachodzi tu zjawisko sprzężenia zwrotnego, tj. czy istota, metoda i cele regulacji gałęzi prawa składających się na prawo prywatne i publiczne wpływają na status (zasady przyznawania prawnej personifikacji, zakres praw i obowiązków, zasada generalna możliwości działania prawnego) podmiotów prywatnoprawnych i publicznoprawnych.

\section{Istota i zakres podmiotowości cywilnoprawnej}

Podmiotowość cywilnoprawna to zespół cech, którymi odznaczają się podmioty tej gałęzi prawa; są to cechy ściśle ze swymi nosicielami

35 Por. E. Łętowska, Umowy - mitologia równości, w: Szkice z teorii prawa i szczegótowych nauk prawnych, red. S. Wronkowska, M. Zieliński, Poznań 1990.

36 Zob. na ten temat S. Prutis, Relacje pomiędzy cywilna a administracyjna metoda regulacji prawnej na przykładzie instytucji prawa rolnego, w: Wspótczesne problemy prawa prywatnego. Księga Pamiątkowa ku czci Profesora Edwarda Gniewka, red. Machnikowski, J. Gołaczyński, Warszawa 2010, s. 495 i n.

37 Zob. M. Safjan, w: System Prawa Prywatnego, t. 1, s. 47 i n. 
związane, pozwalające podmioty cywilnoprawne wskazywać i za takie uznawać, jednocześnie gwarantujące im posługiwanie się mechanizmami cywilnoprawnymi (takimi jak np. umowa) warunkującymi obrót prawny i umożliwiającymi realizację osobistych i majątkowych interesów. Podmiotem prawa cywilnego jest ten, kto jest adresatem norm cywilnoprawnych, kto może być cywilnoprawnie uprawniony lub zobowiązany, kto może być stroną stosunku cywilnoprawnego.

Istotę podmiotowości $\mathrm{w}$ prawie cywilnym wyjaśnia się m.in. za pomocą teorii punktu zaczepienia praw podmiotowych lub punktu odniesienia $\mathrm{w}$ stosunku cywilnoprawnym ${ }^{38}$. W zależności od przyjęcia jednej $\mathrm{z}$ nich, w celu konstruowania szczegółowych wypowiedzi na temat norm cywilnoprawnych używa się wyrażeń: podmiot prawa cywilnego albo podmiot stosunku cywilnoprawnego. Oba kluczowe pojęcia doktrynalne służą określeniu pozycji prawnej konkretnego podmiotu prawnego. Przy zastrzeżeniu, że stroną stosunku cywilnoprawnego jest ktoś w określony sposób uprawniony lub zobowiązany, tyle że w relacji do innej strony, to poprawne i do przyjęcia są obie koncepcje.

Współcześnie na gruncie polskiego prawa cywilnego, co przesądza już art. 1 Kodeksu cywilnego (dalej: K.c.), bez wątpienia podmiotami stosunków cywilnoprawnych są osoby fizyczne i osoby prawne. Jednocześnie ustawodawca w przepisach szczegółowych przyznaje prawo do posiadania praw i obowiązków - przyznając tym samym zdolność prawną - jednostkom, których nie da się zaliczyć ani do grona osób fizycznych, ani osób prawnych. W sposób uogólniony status takich jednostek, niebędących osobami, określa wprowadzony do Kodeksu cywilnego w 2003 r. art. $33^{1} \S 1$, zgodnie z którym do jednostek organizacyjnych niebędących osobami prawnymi, którym ustawa przyznaje zdolność prawną, stosuje się odpowiednio przepisy o osobach prawnych.

Zakres podmiotowy stosunków cywilnoprawnych jest zatem szeroki; status strony uprawnionej lub zobowiązanej cywilnoprawnie mają albo mogą mieć: każdy człowiek i jednostki organizacyjne wyposażone przez przepis ustawy $\mathrm{w}$ zdolność prawną. Tak więc kryterium skutkującym przyznaniem podmiotowości w zakresie prawa cywilnego jest zdolność prawna, czyli przyznawana przez przepis prawny zdolność do bycia podmiotem praw i obowiązków cywilnoprawnych, która jest tym, co wspólne u wszystkich cywilnoprawnie personifikowanych jednostek; jest miarą

38 Zob. A. Stelmachowski, Zarys teorii prawa cywilnego, Warszawa 1998, s. 149 i n. 
podmiotowości w prawie cywilnym. Czasem jednak zdolność prawną traktuje się nie jako kryterium przyznania podmiotowości jednostce, lecz jako synonim jej podmiotowości cywilnoprawnej ${ }^{39}$.

Doktryna cywilistyczna ukształtowana $\mathrm{w}$ pierwszych dziesięcioleciach obowiązywania Kodeksu cywilnego utożsamiała ze sobą pojęcia podmiotowości i osobowości. W reprezentatywnym w tej mierze Systemie Prawa Cywilnego S. Grzybowski pisał, że „Przymiot osobowości polega na zdolności do tego, by być podmiotem stosunków cywilnoprawnych, [...] podmiotem praw i obowiązków. [...] Na terenie prawa cywilnego zakresy jednostek będących osobami (fizycznymi lub prawnymi), jednostek mogących być podmiotami praw i obowiązków oraz jednostek wyposażonych w zdolność prawną pokrywają się ze sobą, a nawet są zakresami tożsamymi" ${ }^{40}$. Ówcześnie sformułowano pogląd, że osobowość (osób fizycznych i osób prawnych) jest kategorią wyłącznie cywilistyczną, zaś podmiotowość, a nawet zdolność prawna to pojęcia należące do słownika także innych gałęzi prawa (np. prawa procesowego, administracyjnego, podatkowego $)^{41}$.

Współcześnie pojęcia podmiotowości i osobowości cywilnoprawnej należy jednak rozróżnić. Między podmiotowością a osobowością prawną zachodzi różnica ilościowa, polegająca na tym, że krąg podmiotów stosunków cywilnoprawnych jest szerszy niż krąg jednostek będących osobami fizycznymi i osobami prawnymi ${ }^{42}$. Parafrazując słowa S. Grzybowskiego, na terenie dziś obowiązującego prawa cywilnego zakresy jednostek będących osobami i zakresy jednostek będących podmiotami praw i obowiązków, tj. jednostek wyposażonych w zdolność prawną - nie pokrywają się ze sobą. Między podmiotowością a osobowością zachodzi także różnica jakościowa - zakres zdolności prawnej podmiotów zbiorowych niebędących osobami prawnymi (np. wspólnoty mieszkaniowe, spółki osobowe) jest węższy i ogranicza się ściśle do praw i obowiązków przypisanych tym podmiotom ze względu na przedmiot i cel działalności - zachodzi zatem różnica między pojęciem osobowości prawnej i podmiotowości prawnej

39 Tak S. Grzybowski, w: System Prawa Cywilnego, t. 1. Część ogólna, Wrocław 1985, s. 284; A. Stelmachowski, Zarys..., s. 155 i 162.

40 Zob. S. Grzybowski, w: System Prawa Cywilnego, t. 1, s. 283.

${ }_{41}$ Tamże, s. 284.

42 Zob. M. Pazdan, w: System Prawa Prywatnego, t. 1, s. 916. 
(osoby prawnej i podmiotu prawnego) ${ }^{43}$. Na gruncie dziś obowiązującego prawa mamy do czynienia nie tylko z doktrynalnym zróżnicowaniem pojęć na podmioty cywilnoprawne i osoby cywilnoprawne, ale także ze zróżnicowaniem jednostek cywilnoprawnie personifikowanych - na jednostki wyposażone w zdolność prawną będące osobami (art. 1, 8 i 33 K.c.) i na takie jednostki, które osobami (prawnymi) nie są (art. $33^{1}$ K.c.). Nastąpiło zatem swoiste odwrócenie trendu w rozwoju prawa i doktryny prawniczej.

Jeżeli chodzi o osoby fizyczne, to konstrukcję ich podmiotowości kształtują reguły: podmiotowość osób fizycznych jest w zasadzie taka sama; reguła ustawowego określenia początku podmiotowości prawnej oraz regulacje prawne pozwalające określić ustanie tejże podmiotowości. Do dodatkowych elementów konstruujących podmiotowość cywilnoprawną człowieka jako osoby fizycznej należą przepisy regulujące zdolność do czynności prawnych i stan cywilny. W sferze prawa prywatnego jednolite pojęcie osoby fizycznej jest wyrazem równości każdego człowieka wobec prawa; jednolite pojęcie osoby fizycznej oznacza zrównanie wszystkich w zakresie ich zdolności prawnej ${ }^{44}$. Co do zasady ten sam i nieograniczony zakres zdolności prawnej wynika z założenia, że podmiotem prawa cywilnego jest człowiek, tylko człowiek i każdy człowiek ${ }^{45}$. Jak stanowi art. 8 § 1 K.c., każdy człowiek od chwili urodzenia ma zdolność prawną. Początek zdolności prawnej wyznacza fakt urodzenia się, zaś koniec śmierć człowieka. Jeśli zaś chodzi o konstrukcję i charakter podmiotowości jednostek organizacyjnych, tj. osób prawnych i podmiotów, o których mowa w art. $33^{1} \S 1$ K.c., to należy zwłaszcza zwrócić uwagę na to, że są one tworami społecznymi, a nie biologicznymi; określić je można jako upodmiotowione jednostki organizacyjne oraz jako podmioty zbiorowe.

43 Zob. tenże, Podmioty bez osobowości prawnej po nowelizacji kodeksu cywilnego z 2003 roku, w: Wkręgu teoretycznych i praktycznych aspektów prawoznawstwa. Księga jubileuszowa profesora Bronistawa Ziemianina, red. M. Zieliński, Szczecin 2005, s. 97.

44 Jak pisał A. Stelmachowski (Zarys..., s. 150), po rewolucji francuskiej, która w sferze prawa prywatnego wymusiła na ustawodawcy (najpierw francuskim, rzecz jasna) odejście od przyznawania pełnej zdolności (podmiotowości) prawnej tylko ludziom wolnym, tylko szlachcicom, duchownym, kupcom itp. na rzecz uznania każdego człowieka za podmiot prawa - jednolite pojęcie osoby fizycznej stało się kamieniem węgielnym wszystkich kodyfikacji cywilnych.

45 Zob. S. Grzybowski, w: System Prawa Cywilnego, t. 1, s. 284. 
Podmiotowość cywilnoprawna jest na tyle istotnym elementem systemu prawa cywilnego, że jej naturę wyjaśnia się także przez odwołanie do zasad prawa cywilnego. Spośród zasad podstawowych prawa cywilnego zwłaszcza zasada autonomii woli powiązana jest z podmiotowością cywilnoprawną. Zresztą zasada autonomii woli, jako wysuwana na czoło i powszechnie w katalogu zasad przedstawiana, jest ujmowana jako na tyle istotna, że bez niej nie da się budować szczegółowych konstrukcji prawa prywatnego - w tym zatem również konstrukcji podmiotowości cywilnoprawnej ${ }^{46}$. Znaczenie związku między problematyką podmiotowości w prawie cywilnym a przywołaną zasadą, ujmowaną szerzej jako zasada autonomiczności podmiotów, zauważał i podkreślał A. Stelmachowski, który w tym celu omawianą zasadę ujmował szerzej, właśnie jako zasadę autonomiczności stron (podmiotów) stosunków cywilnoprawnych. Według tego ujęcia podmioty prawa cywilnego są autonomiczne tak w płaszczyźnie strukturalnej, jak i w funkcjonalnej. Potwierdzeniem strukturalnej autonomiczności podmiotów cywilnoprawnych jest przysługująca im zdolność prawna (art. 8 § 1 i art. 33 K.c.; zob. też art. $33^{1}$ K.c.), natomiast ich funkcjonalna autonomiczność, określana przez Stelmachowskiego jako autonomia woli, przejawia się w swobodzie zawierania i (zwłaszcza) kształtowania treści umów (art. $353^{1}$ K.c.) $)^{47}$. Skoro zasadą jest autonomiczność (woli) podmiotów prawa cywilnego, to nie jest dopuszczalna rozszerzająca wykładnia przepisów wprowadzających ograniczenia tejże autonomiczności.

Podmiotowość cywilnoprawną, a właściwie pewną wyjątkową cechę podmiotów cywilnoprawnych uznać należy za jedno z podstawowych kryteriów wyróżniania prawa cywilnego w systemie prawa. W tym kontekście znaczenie podmiotowości cywilnoprawnej docenia się w doktrynie; Stelmachowski, który do "filarów, na jakich opiera się system prawa cywilnego" zaliczył instytucje własności i odpowiedzialności cywilnej, problematyce podmiotowości $\mathrm{w}$ prawie cywilnym poświęcił odrębną część swego dzieła Zarys teorii prawa cywilnego ${ }^{48}$, formułując wyjściową dla całej swej pracy tezę, że podstawową, najbardziej charakterystyczną cechą prawa cywilnego jest autonomiczność jego podmiotów. Rolę szczególnego statusu podmiotów cywilnoprawnych wyeksponował w twierdzeniu,

\footnotetext{
${ }^{46}$ Zob. M. Safjan, w: System Prawa Prywatnego, t. 1, s. 273.

47 Zob. A. Stelmachowski, Zarys..., s. 83 i n.

48 Tamże, s. 149 i n.
} 
że „[...] zasadniczymi cechami wyróżniającymi prawo cywilne i oparte na nim stosunki cywilnoprawne są: autonomiczność podmiotów oraz brak bezpośredniego przymusu ze strony państwa". Autonomiczność podmiotów na równi z brakiem bezpośredniego przymusu ze strony państwa (w sferze stosunków cywilnoprawnych) uznawał za cechy, które stanowią o istocie prawa cywilnego ${ }^{49}$. Dodać można, że Stelmachowski powoływał się na węgierskiego prawnika G. Eörsiego ${ }^{50}$, który prawo cywilne definiował jako gałąź prawa regulującą stosunki między autonomicznymi podmiotami, samą zaś autonomiczność podmiotów stosunków cywilnoprawnych uznawał za oś konstrukcyjną i podstawową zasadę prawa cywilnego ${ }^{51}$.

Autonomiczność jest wyrazem statusu prawnie personifikowanych jednostek działających „w środowisku” systemu prawa cywilnego, w myśl cywilistycznej metody regulacji stosunków społecznych. Przejawy i gwarancje wspomnianej autonomiczności są następujące. Po pierwsze, podmioty prawa cywilnego mają prawo swobodnego kształtowania treści stosunków prawnych, w których występują jako strona; po drugie, relacja prawna między podmiotami stosunku cywilnoprawnego opiera się na braku władczego podporządkowania jednego podmiotu drugiemu; po trzecie, podmioty cywilnoprawne są prawnie równorzędne jeden wobec drugiego; po czwarte wreszcie, każdy podmiot uprawniony i zobowiązany we własnym imieniu i na własny rachunek powinien realizować swoje interesy (w zakresie uprawnienia albo obowiązku), a ponadto rozstrzyganie sporów między podmiotami następuje mocą rozstrzygnięcia sądu, który orzeka w sprawie co do zasady z inicjatywy zainteresowanego.

\section{Podmiotowość administracyjnoprawna}

Z kolei podmiotowość administracyjna ujmowana jest $\mathrm{w}$ doktrynie jako „stworzony przez prawo administracyjne punkt zarachowania

\footnotetext{
49 Tamże, s. 35.

50 G. Eörsi, Principles of the Socialist Civil Law, Budapest 1970.

51 Zob. A. Stelmachowski, Zarys..., s. 35.
} 
uprawnień i obowiązków" ${ }^{\prime 2}$. Cechą podmiotowości administracyjnej jest duża liczba „lokalizacji” wspomnianych „punktów zarachowania” i różnorodność postaci organizacyjnych oraz form działania „obiektów” będących podmiotami administracyjnymi, co przekłada się na zróżnicowanie nomenklatury i zróżnicowanie pozycji prawnej w systemie administracji. Znaczenie podstawowe, jako powszechnie i najdłużej używane, ma pojęcie podmiotu administracji publicznej; jest to pojęcie o charakterze doktrynalnym, niezdefiniowane mocą przepisów prawnych. Pojęcia podmiotu administracji publicznej lub władzy publicznej, podmiotu administrującego lub podmiotu prawa publicznego, wreszcie organu administracji publicznej (organu administrującego) - to określenia służące oznaczeniu rozmaitych jednostek wykonujących zadania administracji publicznej. Nie są to określenia synonimiczne, różnią się wzajemnie, a ich wielość i zróżnicowanie znaczeniowe wynika zarówno ze zmienności i zróżnicowania katalogu zadań administracyjnych, jak i systemu organizacyjnego i funkcjonalnego, który tworzy ramy działania administracji. Dodać należy, że są to konstrukcje normatywne, jednostki organizacyjne zróżnicowane także pod względem zakresu administracyjnoprawnej podmiotowości (np. gmina ma własne prawo do sprawowania samorządowej władzy publicznej, jest podmiotem lokalnej administracji, ma własne zadania, a w ich zakresie działa na zasadzie domniemania kompetencji; zaś wójt gminy jest organem administracji publicznej o ściśle określonym zakresie praw i obowiązków). Tak więc wymienione określenia mają wspólną cechę, gdyż służą oznaczeniu jednostek wykonujących zadania publiczne, a jednocześnie „mają inne punkty odniesienia” 53 .

Przy tym współcześnie coraz częściej, jako zakresowo najszerszego, używa się określenia „podmiot administrujący”. Podmioty administrujące są kreowane przez prawo i są funkcjonalnie powiązane (bezpośrednio, pośrednio, wyłącznie, w określonym stopniu) z zadaniami publicznymi. W najogólniejszym sensie rozpatrywanie podmiotowego aspektu administracji związane jest z personifikacją prawną państwa, a także, w konsekwencji decentralizacji, $\mathrm{z}$ „istnieniem” innych publicznych osób prawnych. Osobowość prawna państwa i innych odrębnych względem państwa

52 Zob. J. Filipek, O podmiotowości administracyjnoprawnej, Państwo i Prawo 1961, z. 2, s. 199 i n.; zob. też M. Stahl, w: System Prawa Administracyjnego, t. 6. Podmioty administrujące, red. R. Hauser, Z. Niewiadomski, A. Wróbel, s. 50 i n.

53 Zob. M. Stahl, w: System Prawa Administracyjnego, t. 6, s. 11. 
jednostek organizacyjnych jest podstawą sieci podmiotów i organów administrujących. Osobowość prawna jest oparciem dla praw i kompetencji publicznoprawnych, a organy państwa i organy innych publicznych osób prawnych są podstawą konstrukcji wykonywania władztwa publicznego, administracyjnego (imperium) ${ }^{54}$.

Podmiotowość administracyjna jest postacią podmiotowości prawnej, a podmiot administracji jest formą podmiotu prawnego i w konsekwencji, jak stwierdza M. Stahl, „mają do niego zastosowanie ogólne reguły podmiotowości prawnej”. W szczególności podstawą jego podmiotowości jest zdolność prawna w zakresie władzy i zadań publicznych, której źródłem są normy prawa publicznego ${ }^{55}$. Przy czym ustalenia doktryny w dziedzinie struktury i zakresu podmiotowości administracyjnej nie są jednoznaczne i różnią się w szczegółach ujęcia. Przykładowo J. Niczyporuk rozróżnia pojęcia podmiotu administracji publicznej i podmiotów administrujących; pojęcie podmiotów administrujących obejmuje szerszy zakres organizacji wykonujących kompetencje administracyjne - a według przywołanego Autora należą do nich również wewnętrzne jednostki organizacyjne podmiotów administracji ${ }^{56}$. Jak się wydaje, przyjąć można, że podmiot administracji publicznej jest podmiotem zadań publicznych i podmiotem praw i obowiązków z zakresu prawa administracyjnego, zaś podmiot administrujący spełnia określone funkcje $\mathrm{w}$ zakresie reprezentacji podmiotu administracji publicznej w stosunkach prawnych zewnętrznych. Podmiot administracji ma zdolność prawną $\mathrm{w}$ zakresie stosunków administracyjnoprawnych, natomiast podmioty administrujące wyposażone są w "specyficzną podmiotowość administracyjnoprawną, lecz wtedy oznacza ona zdolność do czynności prawnych. Przez zdolność do czynności prawnych należy [...] uznać to, że podmioty administrujące mogą stosownie do norm prawa administracyjnego wyrażać wolę podmiotów administracji w zakresie ich praw i obowiązków" ${ }^{\prime 57}$. Chodzi przy tym o aktywny udział przejawiający się $\mathrm{w}$ realizacji kompetencji w obrocie administracyjnoprawnym; o podejmowanie w nim szczególnych czynności prawnych - właściwie czynności administracyjnoprawnych, które powoływany autor określa mianem

54 Tamże, s. 12.

55 Tamże, s. 21.

56 J. Niczyporuk, Reprezentacja podmiotów prawa administracyjnego, w: Koncepcja systemu prawa administracyjnego, s. 305.

57 Tamże. 
„zdarzeń prawnych zmierzających do osiągnięcia skutku prawnego w prawie administracyjnym". Zdaniem Niczyporuka pojęcie zdolności do czynności prawnych, przy zdiagnozowaniu tendencji przenoszenia dorobku doktryny prawa cywilnego na grunt pozostałych gałęzi prawa ${ }^{58}$, ujmować należy jako pojęcie charakterystyczne dla całości prawa (dla wszystkich gałęzi systemu prawa) ${ }^{59}$. Konsekwencją takiego ujęcia jest teza, że zdolność prawną (administracyjnoprawną) ma podmiot administracji, zaś zdolność do czynności administracyjnoprawnych jest atrybutem organu administracji publicznej. Z tym że zdolność prawna na gruncie prawa administracyjnego oznacza nie tylko abstrakcyjną i potencjalną możność bycia podmiotem praw i obowiązków, lecz także realne posiadanie konkretnych praw i obowiązków; byt podmiotu administracji jest realny, a zdolność administracyjnoprawna odnosi się do konkretnych praw i obowiązków danego podmiotu administracji ${ }^{60}$. Istota zdolności do czynności prawnych polega na tym, że organ administracji, stosownie do norm prawa administracyjnego, może wyrażać wolę podmiotu administracji (np. państwa, terytorialnej korporacji publicznej, zakładu publicznego) w zakresie jego praw i obowiązków ${ }^{61}$.

\section{Osoby prawne prawa publicznego}

Odrębną, szczególną, w pewnym sensie podstawową kategorią podmiotów są osoby prawne prawa publicznego (publicznoprawne). Obok państwa do osób prawnych prawa publicznego zaliczyć można jednostki samorządu terytorialnego. Prawna personifikacja jednostek samorządu

58 Przywołany Autor podkreśla także, że ścisły związek między pojęciem zdolności do czynności prawnych a pojęciem organu administracji publicznej charakteryzuje stanowisko niemieckiej doktryny prawniczej; por. H. Maurer, Ogólne prawo administracyjne. Allgemeines Verwaltungsrecht, tłum. i red. K. Nowacki, Wrocław 2003, s. 234-235.

59 J. Niczyporuk, Zdolność do czynności prawnych organu administracji publicznej, w: Ewolucja prawnych form administracji publicznej. Księga jubileuszowa z okazji 60. rocznicy urodzin Profesora Ernesta Knosali, red. L. Zacharko, A. Matan, G. Łaszczyca, Warszawa 2008, s. 217; zob. też L. Kociucki, Pojęcie zdolności do czynności prawnych osób fizycznych-zagadnienia konstrukcyjne, w: Prawo w XXI wieku. Księga pamiątkowa 50-lecia Instytutu Nauk Prawnych Polskiej Akademii Nauk, red. W. Czapliński, Warszawa 2006, s. 364 i n.; tenże, Zdolność do czynności prawnych osób dorostych i jej ograniczenia, Warszawa 2011, s. 107 i n.

60 Tak J. Niczyporuk, Zdolność do czynności prawnych..., s. 221.

61 Zob. tamże, s. 219 i n. 
terytorialnego ma ścisły, pochodny związek z prawem do sprawowania władzy publicznej, są to instytucje wchodzące w zakres podmiotowy administracji publicznej; podmioty prawa publicznego, których funkcja jest zaspokajanie potrzeb społeczności lokalnej. Jak się przyjmuje w doktrynie, osobowość prawna jednostek samorządu terytorialnego obejmuje możność stosowania władztwa administracyjnego oraz zdolność do działania na podstawie norm prawa prywatnego. Oznacza to, że złożona podmiotowość prawna jednostek samorządu terytorialnego skupia się funkcjonalnie w ramach konstrukcji szczególnej osoby prawnej ${ }^{62}$.

Według prawa istota gmin, powiatów i województw polega na tym, że są one osobami prawnymi, terytorialnymi korporacjami, którym przypisano prawa i obowiązki wykonywania zadań publicznych, a tym samym są osobami prawa publicznego ${ }^{63}$. Oparciem dla tak określonej koncepcji są przepisy art. 15 i art. 16 Konstytucji RP. Jednocześnie, co jest głównym argumentem przeciwników uznania jednostek samorządu terytorialnego za osoby prawne prawa publicznego, Konstytucja RP w swoim tekście takim pojęciem się nie posługuje ${ }^{64}$.

Według P. Radziewicza posługiwać się wręcz nie może, gdyż tylko państwo, jako podmiot pierwotnej i suwerennej władzy, jest osobą prawną prawa publicznego (co nie wyklucza podmiotowości samorządu terytorialnego w zakresie prawa publicznego). Samorząd terytorialny jest powołany przez państwo wyłącznie do realizacji jego zadań, a podmiotowość

${ }^{62}$ Gminy, powiaty i województwa jako jednostki samorządu terytorialnego mają szczególny status samorządowej osoby prawnej. Według na ogół przyjmowanego rozumienia są to osoby prawne szczególnego rodzaju, posiadające specyficzne prawa i obowiązki wynikające z wykonywania przez nie funkcji publicznych. Pogląd, w myśl którego gminy, powiaty i samorządy województw są samorządowymi osobami prawnymi uznać można za zgodny z koncepcją jednostek samorządu terytorialnego jako osób prawnych prawa publicznego. Z tym zastrzeżeniem, że prawo w określonym kontekście posługuje się kategorią tzw. innych samorządowych osób prawnych, do których zalicza spółki i przedsiębiorstwa komunalne, w stosunku do których funkcje założycielskie spełnia jednostka samorządu terytorialnego; zob. A. Doliwa, Osobowość prawna jednostek samorządu terytorialnego, Warszawa 2012; S. Czarnow, Samorządowe osoby prawne - perspektywa nowej regulacji, Samorząd Terytorialny 2009, nr 7-8, s. 38 i n.

63 Zob. W. Miemiec, M. Miemiec, Podmiotowość publicznoprawna gminy, Samorząd Terytorialny 1991, nr 11-12, s. 15 i n.

64 Na marginesie zauważyć można, że Konstytucja również w odniesieniu do państwa określenia „osoba prawna prawa publicznego" nie używa. Por. I. Lipowicz, Dylematy zmiany siatki pojęciowej w nauce prawa administracyjnego, w: Koncepcja systemu prawa administracyjnego, s. 22 i n. 
jednostek samorządu terytorialnego nie jest tożsama z osobowością publicznoprawną. Osobowość publicznoprawna samorządu nie istnieje, nie ma żadnej odrębnej od państwa osobowości w sferze prawa publicznego, gdyż tylko państwo jest podmiotem własnego, naturalnego i faktycznego władztwa publicznego. Samorząd terytorialny jest integralną częścią państwa, jego administracji, a źródłem praw samorządu jest ustanowione przez państwo prawo ${ }^{65}$.

Przeciwnego zdania jest S. Fundowicz, który twierdzi, że istotą decentralizacji jest samodzielność nie organów, jak dotychczas na ogół twierdzono, lecz podmiotów administracji. Z decentralizacją mamy do czynienia, gdy w porządku prawnym istnieją osoby prawne prawa publicznego, którymi są także podmioty utworzone przez państwo dla wykonywania zadań publicznych we własnym imieniu i na własną odpowiedzialność. Realizacją zasady ustrojowej w Rzeczypospolitej Polskiej, której celem była decentralizacja władzy publicznej, było ustanowienie jednostek samorządu terytorialnego. Są one podmiotami prawnymi, osobami prawa publicznego, a potwierdzeniem ich samodzielności jest możliwość stanowienia prawa lokalnego i samodzielne prowadzenie gospodarki finansowej ${ }^{66}$.

Słusznie zauważa A. Wiktorowska, że konstytucyjne przepisy ustanawiające na rzecz jednostek samorządu terytorialnego prawo do wykonywania $\mathrm{w}$ imieniu własnym i na własną odpowiedzialność istotnej części zadań publicznych, łącznie ze sprawowaniem przez gminy oraz powiaty i samorządy województw, będące osobami prawnymi, funkcji publicznych przy użyciu władztwa administracyjnego, nadają przez to jednostkom samorządu terytorialnego atrybuty podmiotów publicznoprawnych; osób prawa publicznego. „Obowiązujące prawo RP nie posługuje się [...] terminem osoba prawa publicznego, stąd też dyskusyjna jest możliwość posługiwania się nim de lege lata w języku prawniczym. Nie przeszkadza to jednak rozważaniom doktrynalnym i teoretycznym" ${ }^{67}$.

Jako kluczowe zagadnienie w ogóle dla podmiotowości prawnej w administracji publicznej instytucję osobowości publicznoprawnej traktują

65 Zob. P. Radziewicz, Kilka uwag w sprawie prawnej przydatności pojęcia „osoba prawa publicznego", Samorząd Terytorialny 2000, nr 6, s. 3 i n.

66 Zob. S. Fundowicz, Decentralizacja administracji publicznej w Polsce, s. 285-286.

67 Zob. A. Wiktorowska, Prawne determinanty samodzielności gminy. Zagadnienia administracyjnoprawne, Warszawa 2002, s. 81 i n. 
W. Miemiec i M. Miemiec, piszący o podmiotowości gminy. Twierdzą oni, odwołując się do zasady i zjawiska decentralizacji administracji publicznej, że "[...] gmina jest już w obecnym stanie regulacji prawnej osobą prawną prawa publicznego. Jednak kwestia osobowości publicznoprawnej gminy powinna być wyraźnie uregulowana przez ustawę" ${ }^{\prime \prime}$.

Zdaniem S. Fundowicza powyższą kwestię rozpatrywać należy przez odwołanie się do aksjologicznych założeń ustroju Rzeczypospolitej Polskiej, takich jak godność i wolność człowieka, które określają także zasadę decentralizacji administracji publicznej. Autor rozważań dochodzi w ten sposób do wniosku, że nie można absolutyzować władzy państwa i wprowadzać w sferze prawa publicznego jego omnipotencji. Jedność administracji publicznej nie wyklucza wykonywania jej przez różne, w tym samodzielne wobec państwa podmioty ${ }^{69}$. Trafnie zauważa, że mimo braku wyraźnego określenia charakteru osobowości prawnej jednostek samorządu terytorialnego powiązanie jej w jednym przepisie prawa pozytywnego z wykonywaniem zadań publicznych w imieniu własnym i na własną odpowiedzialność pozwala, wraz z ustanowioną w art. 165 ust. 2 Konstytucji RP zasadą sądowej ochrony samodzielności gmin, powiatów i samorządów województw, na określenie tejże osobowości jako publicznoprawnej. Fundowicz w swym rozumowaniu, dla podkreślenia wagi takiego charakteru osobowości prawnej gmin, powiatów i samorządów województw wręcz zamienia miejsca przesłanki i wniosku, pisząc: „To dlatego, że jednostka samorządu terytorialnego ma osobowość prawną, może ona wykonywać zadania publiczne we własnym imieniu i na własną odpowiedzialność i dlatego też może samodzielnie te zadania wykonywać, a samodzielność ta podlega ochronie sądowej"70.

\section{Zakończenie}

W podsumowaniu stwierdzić należy, że podmiotowość w prawie, choć należy do konstrukcji podstawowych i klasycznych, wciąż jest zagadnieniem inspirującym, a adaptacja treści pojęcia podmiotowości do celów

\footnotetext{
68 W. Miemiec, M. Miemiec, Podmiotowość publicznoprawna gminy, s. 19.

69 Tamże, s. 106.

70 Tamże, s. 107.
} 
regulacyjnych prawa w przyszłości, wyznaczanych takimi zjawiskami jak sztuczna inteligencja, stwarza pole dla nowej refleksji naukowej. Rozróżnienie prawa prywatnego i publicznego, zwłaszcza według kryterium celu i metody regulacji, ma istotną doniosłość teoretyczną i wpływa na pojmowanie podmiotowości cywilnoprawnej (prywatnoprawnej) i administracyjnoprawnej (publicznoprawnej), w tym zwłaszcza stanowi użyteczny kontekst teoretyczny formułowania koncepcji osób prawnych prawa publicznego. Również określona aksjologia stanowiąca fundament szczegółowych regulacji publicznoprawnych albo prywatnoprawnych wpływa na status podmiotów tych zasadniczych części systemu prawnego. Podkreślenia wymaga, że konstrukcja podmiotów prywatnoprawnych zbudowana jest na fundamencie autonomiczności i poszanowania godności każdej jednostki ludzkiej, co oznacza, że zakres ich kompetencji w stosunkach prawnych jest możliwie szeroki, oparty na zasadzie kompetencji generalnej (zakazy prawne w tej mierze mają charakter wyjątku). Natomiast konstrukcja podmiotów publicznoprawnych opiera się na zasadzie legalizmu, ich działania w ramach stosunków prawnych możliwe są jedynie na szczególnej podstawie prawnej i w jej granicach. Podział ten jednak nie jest rozłączny, gdyż podmioty publicznoprawne, w tym zwłaszcza osoby prawne prawa publicznego, takie jak jednostki samorządu terytorialnego, mają ustawowe i konstytucyjne prawo do własności i innych praw majątkowych, a więc wyposażone są również w podmiotowość cywilnoprawną.

\section{Bibliografia}

Austin J.L., Mówienie i poznawanie, Warszawa 1993.

Bigo T., Zwiazki publiczno-prawne w świetle ustawodawstwa polskiego, Warszawa 1928.

Boryś W., Stownik etymologiczny języka polskiego, Kraków 2005.

Breczko A., Podmiotowość prawna człowieka w warunkach postępu biotechnomedycznego, Białystok 2011.

Czarnow S., Samorzadowe osoby prawne - perspektywa nowej regulacji, Samorząd

Terytorialny 2009, nr 7-8.

Doliwa A., Osobowość prawna jednostek samorzadu terytorialnego, Warszawa 2012.

Duniewska Z., w: System Prawa Administracyjnego, t. 1. Instytucje prawa administracyjnego, red. Z. Niewiadomski, Warszawa 2010.

Eörsi G., Principles of the Socialist Civil Law, Budapest 1970. 
Filipek J., O podmiotowości administracyjnoprawnej, Państwo i Prawo 1961, z. 2.

Filipek J., Podmiotowość w prawie administracyjnym, w: Podmioty administracji publicznej i prawne formy ich działania. Studia i materiaty z konferencji naukowej poświęconej jubileuszowi 80-tych urodzin profesora Eugeniusza Ochendowskiego, Toruń 2005.

Frąckowiak J., Jednostka organizacyjna jako substrat osoby prawnej $i$ ustawowej, w: Rozprawy prawnicze. Księga pamiątkowa Profesora Maksymiliana Pazdana, red. L. Ogiegło, W. Popiołek, M. Szpunar, Kraków 2005.

Frąckowiak J., w: System Prawa Prywatnego, t. 1. Prawo cywilne - część ogólna, red. M. Safijan, Warszawa 2007.

Fundowicz S., Dychotomiczny podział prawa, Samorząd Terytorialny 2000, nr 1-2. Grzybowski S., w: System Prawa Cywilnego, t. 1. Część ogólna, Wrocław 1985.

Kalinowski M., Podmiotowość prawna podatnika, Torun 1999.

Kociucki L., Pojęcie zdolności do czynności prawnych osób fizycznych - zagadnienia konstrukcyjne, w: Prawo w XXI wieku. Ksiega pamiątkowa 50-lecia Instytutu Nauk Prawnych Polskiej Akademii Nauk, red. W. Czapliński, Warszawa 2006.

Kociucki L., Zdolność do czynności prawnych osób dorostych i jej ograniczenia, Warszawa 2011.

Kruszewska-Gagoś M., Podmiotowość publicznoprawna gminy, Lublin 2009.

Lacey A.R., Słownik filozoficzny, tłum. R. Matuszewski, Poznań 1999.

Lipowicz I., Dylematy zmiany siatki pojecciowej w nauce prawa administracyjnego, w: Koncepcja systemu prawa administracyjnego, red. J. Zimmermann, Warszawa 2007.

Łączkowski W., Ustrojowe podstawy prawa publicznego, w: Studia z Prawa Publicznego, t. 1, Lublin 1999.

Łętowska E., Umowy - mitologia równości, w: Szkice z teorii prawa i szczegótowych nauk prawnych, red. S. Wronkowska, M. Zieliński, Poznań 1990.

Maurer H., Ogólne prawo administracyjne. Allgemeines Verwaltungsrecht, tłum. i red. K. Nowacki, Wrocław 2003.

Miemiec W., Miemiec M., Podmiotowość publicznoprawna gminy, Samorząd Terytorialny 1991, nr 11-12.

Namysłowska-Gabrysiak B., Odpowiedzialność karna osób prawnych, Warszawa 2003.

Niczyporuk J., Reprezentacja podmiotów prawa administracyjnego, w: Koncepcja systemu prawa administracyjnego, red. J. Zimmermann, Warszawa 2007.

Niczyporuk J., Zdolność do czynności prawnych organu administracji publicznej, w: Ewolucja prawnych form administracji publicznej. Księga jubileuszowa z okazji 60. rocznicy urodzin Profesora Ernesta Knosali, red. L. Zacharko, A. Matan, G. Łaszczyca, Warszawa 2008.

Nowacki J., Prawo publiczne, prawo prywatne, Katowice 1992. 
Pazdan M., Podmioty bez osobowości prawnej po nowelizacji kodeksu cywilnego z 2003 roku, w: W kregu teoretycznych i praktycznych aspektów prawoznawstwa. Księga jubileuszowa profesora Bronistawa Ziemianina, red. M. Zieliński, Szczecin 2005.

Peretiatkowicz A., Podstawowe pojęcia prawa administracyjnego, Poznań 1947.

Pieńkos J., Podstawy juryslingwistyki. Język w prawie - Prawo w języku, Warszawa 1999.

Prutis S., Relacje pomiędzy cywilna a administracyjna metoda regulacji prawnej na przykładzie instytucji prawa rolnego, w: Współczesne problemy prawa prywatnego. Księga Pamiatkowa ku czci Profesora Edwarda Gniewka, red. P. Machnikowski, J. Gołaczyński, Warszawa 2010.

Radwanowicz J., Istota i znaczenie pojęcia przymusu administracyjnego, w: Koncepcja systemu prawa administracyjnego, red. J. Zimmermann, Warszawa 2007.

Radwański Z., Pojęcie prawa cywilnego w świetle kodeksu cywilnego (uwagi de lege lata $i$ de lege ferenda), w: Polskie prawo prywatne w dobie przemian. Ksiega jubileuszowa dedykowana Profesorowi Jerzemu Młynarczykowi, Gdańsk 2005.

Radziewicz P., Kilka uwag w sprawie prawnej przydatności pojęcia „osoba prawa publicznego", Samorząd Terytorialny 2000, nr 6.

Rajca L., Gmina jako podmiot władzy publicznej i jako właściciel mienia, Warszawa 2001.

Rot H., Problem dychotomii prawa publicznego i prywatnego, Przegląd Prawa i Administracji 1976, t. 7.

Stownik łacińsko-polski, t. 5, red. M. Plezia, Warszawa 1999.

Stelmachowski A., Zarys teorii prawa cywilnego, Warszawa 1998.

System Prawa Administracyjnego, t. 6. Podmioty administrujace, red. R. Hauser, Z. Niewiadomski, A. Wróbel, Warszawa 2011.

Wach M., Status ułomnych osób prawnych w polskim prawie cywilnym, Warszawa 2008.

Wiktorowska A., Prawne determinanty samodzielności gminy. Zagadnienia administracyjnoprawne, Warszawa 2002.

Włodyka S., Problem struktury prawa, Państwo i Prawo 1995, z. 4.

Wronkowska S., Podstawowe pojęcia prawa i prawoznawstwa, Poznań 2005.

Wróblewski J., Teorie osób prawnych - zarys podejścia semiotycznego, w: Studia z prawa cywilnego. Księga pamiątkowa dla uczczenia 50-lecia pracy naukowej prof. dr. hab. Adama Szpunara, red. A. Rembieliński, Łódź 1983.

Ziembiński Z., O metodzie analizowania stosunku prawnego, Państwo i Prawo 1967, z. 2.

Ziembiński Z., Problemy podstawowe prawoznawstwa, Warszawa 1980.

Zimmermann M., Z zagadnień definicji prawa administracyjnego, Acta Universitatis Wratislaviensis. Prawo 1964, t. 12, nr 19. 


\section{Streszczenie}

Przedmiotem opracowania są teoretyczne aspekty zagadnienia podmiotowości prawnej definiowanej na tle podziału systemu prawnego na prawo publiczne i prawo prywatne. Po przedstawieniu rozumienia ogólnego pojęcia podmiotu prawnego oraz relacji i kryteriów wyróżniania pojęć: prawo publiczne i prawo prywatne następuje analiza najważniejszych problemów w zakresie podmiotowości cywilnoprawnej i podmiotowości publicznoprawnej. Celem rozważań jest wykazanie, że w odniesieniu do pojęcia osobowości prawnej (podmiotowości osób prawnych) ustalenia doktryny prawa cywilnego są uniwersalne i mogą stanowić punkt wyjścia dla konstruowania pojęcia osobowości publicznoprawnej. To ostatnie pojęcie uznane zostało za użyteczne w szczególności jako narzędzie analizy pozycji ustrojowej jednostek samorządu terytorialnego w państwie.

Słowa kluczowe: podmiot prawa, prawo publiczne, prawo prywatne, osoba prawna, osoba prawna prawa publicznego

\section{LEGAL SUBJECTIVITY IN THE LIGHT OF THE DIVISION OF LAW INTO PUBLIC AND PRIVATE}

\section{Sum ma ry}

The subject of the study are the theoretical aspects of the issue of legal subjectivity defined against the background of the division of the legal system into public law and private law. After presenting a general understanding of the concept of a legal entity, as well as relations and criteria for distinguishing the terms: public law and private law, the most important problems in the field of civil law and administrative law subjectivity are analyzed. The purpose of the discussion is to show that in relation to the concept of legal personality (subjectivity of legal persons), the doctrines of civil law are universal and can be a starting point in constructing the concept of public law personality. The latter concept was considered useful in particular as a tool for analyzing the political position of local government units.

Key words: legal entity, public law, private law, legal person, legal person of public law 


\section{ПРАВОСУБЪЕКТИВНОСТЬ В КОНТЕКСТЕ РАЗДЕЛЕНИЯ СИСТЕМЫ ПРАВА НА ЧАСТНОЕ И ПУБЛИЧНОЕ}

\section{Резюме}

Предметом исследования являются теоретические аспекты вопроса правосубъективности, определяемые на фоне разделения правовой системы на публично-правовую и частноправовую. После представления понимания общего понятия субъекта права, а также отношений и критериев для разграничения понятий: публичное право и частное право, анализируются наиболее важные проблемы в области гражданской и публичной правосубъективности. Целью статьи является показать, что в отношении понятия правосубъектности (правосубъективности юридических лиц) положения доктрины гражданского права универсальны и могут служить отправной точкой для построения концепции понятия правосубъектности юридических лиц публичного права. Последняя концепция оказалась полезной, в частности, в качестве инструмента для анализа положения органов местного самоуправления в рамках конституционного строя в государстве.

Ключевые слова: субъект права, публичное право, частное право, юридическое лицо, юридическое лицо публичного права 
